\title{
REPRESENTATION AND PERCEPTION \\ OF IMPERIAL POWER IN AD 238. \\ THE NUMISMATIC EVIDENCE ${ }^{1}$
}

\author{
By \\ KAREN HAEGEMANS
}

On an unspecified day early in 235 the prestige of the Roman senate suffered a severe blow. Not only was one of their most favoured emperors, the courteous Alexander Severus, killed by his own soldiers, but he was replaced by a man who allegedly started his career as a Thracian shepherd, the barbarian C. Iulius Verus Maximinus. ${ }^{2}$ Until then, the Roman Empire had enjoyed relative stability. To be sure, there had been some troubled years and even humiliations. Romans would have need only remember the year 69, which saw four emperors, a year that started, according to Tacitus, "a period rich in disasters, terrible with battles, torn by civil struggles, horrible even in peace". ${ }^{3}$ Or maybe 193, when the empire was sold to the highest bidder. Evil emperors came to power, as in the case of Elagabalus, a man no decent Roman aristocrat would have preferred to see on the throne. But the least that can be said is that it was always a man of proper descent who ruled the empire. The senate had had to accept men who came from equestrian origins as Macrinus, or men who, even though senators, favoured the army, but never before had a man from such low ancestry come to the throne. In 235 Maximinus Thrax, who had started his life as a military man from humble origins, was promoted to the highest rank in the empire, the rank of princeps. Ruling the empire together with his son Maximus, he kept this position until 238, when a revolution in Africa announced his loss of legitimacy in the eyes of the aristocracy.

Herodian informs us that, in $\mathrm{AD} 238$, some young African landowners from Thysdrus (the modern El-Djem), weary of fiscal oppression, killed a government official and, fearing for retribution, forced the elderly proconsul of the provincia Africa, M. Antonius Gordianus, to assume the

\footnotetext{
${ }^{1}$ It is a pleasure to thank Professors Katelijne Vandorpe and Kenneth Harl for their kind help and useful suggestions. I am also largely indebted the American Numismatic Society in New York for the research opportunities they offered me. All the coin pictures are reproduced by courtesy of the ANS, with the exception of the coin in Plates VIII, fig. 9, which is part of a private collection. In this paper RIC IV 2 is H. Mattingly, E.A. Sydenham \& C.H.V. Sutherland, The Roman Imperial Coinage IV 2: Macrinus to Pupienus (London 1938).

${ }^{2}$ Herodian 6.8.1; 7.1.2.

${ }^{3}$ Tacitus, Historiae 1.2; all translations cited in this paper are taken from the Loeb text editions.
} 
purple, a man who "had held many other previous provincial commands and proved his ability in important achievements". ${ }^{4}$ Gordian I Africanus appointed his son and namesake Gordian II co-emperor. Accepting imperial power from rebels while the hated opponent still lived, proved dangerous, and so, as expected, the new emperors quickly came to an untimely end. Both died three weeks after their accession to the throne as a result of a battle near Carthage forced upon them by Capellianus, an army-commander faithful to Maximinus. During the short span of their rule the senate, however, had accepted the news of the insurrection in a way unique in Roman imperial history: the senators immediately supported, apparently without hesitation, the rebellion, declared Maximinus enemy of the state and took a prominent role in the further events.

With the deaths of the Gordiani and Maximinus still alive, the Senate had to take other measures swiftly. From an earlier elected committee of twenty advisors of senatorial rank, two were chosen to replace the Gordiani: $M$. Clodius Pupienus Maximus and D. Caelius Calvinus Balbinus. Within weeks after these two rulers had assumed the power, Maximinus was killed by his own soldiers while besieging Aquileia, an important trading post and logistic centre in northeast Italy. It is clear that these two emperors received a much more positive assessment by Herodian than did Maximinus. Pupienus, as Herodian tells us, "had held many military commands and the prefecture of the city...; public opinion considered him an intelligent and shrewd man of sober habits. Balbinus came from a patrician family, had held two consulships and had been a provincial governor without giving cause for complaint". ${ }^{5}$ Yet the people of Rome and the army seem not to have agreed with the senatorial choice. They demanded that the dynastic succession of the Gordiani be upheld by making the grandson of Gordian I (through his daughter) Caesar. Gordian III thus became, after Maximus, the second Caesar of the year, and within three months he was promoted to sole Augustus after Pupienus and Balbinus were murdered by the Praetorian Guard.

Given the rapid changes of power in 238 , the respective emperors certainly had an interest in making themselves known to their subjects. In this regard, coinage would be an ideal medium, since it could have access to a large range of people. ${ }^{6}$

\footnotetext{
${ }^{4}$ Herodian 7.5.2.

${ }^{5}$ Herodian 7.10.4. Cf. P.M.M. Leunissen, Konsuln und Konsulare in der Zeit von Commodus bis Severus Alexander (Amsterdam 1989), 115, 227, 247 and 311.

${ }^{6} \mathrm{C}$. Ando, Imperial Ideology and Provincial Loyalty in the Roman Empire (Berkeley 2000), 215.
} 
Even though some of these emperors reigned for a very brief time, the mint of Rome issued coins for all of them. As there would have been no point for the imperial mint to strike coins for a dead emperor, Rome was the only mint where it was certain that the coins were minted during the lifetime of the appropriate emperor, or in the case of the Gordiani before the news of their death reached the capital. The minting of coins for Maximinus and Maximus, on the other hand, would have stopped as soon as the Roman senate declared them enemies of the state. We can assume, therefore, that the issues in Rome were all ordered by the governing emperors, if not in person than certainly by their administrators. ${ }^{7}$ The possibility exists that the emperors made efforts of legitimisation of their power through their coinage.

The provincial mints are a different matter. Strangely enough we have coins of cities throughout the empire for all of the emperors of 238 , both Augusti and Caesares. Even though in most cases they seem to have been struck during the assumed lifetime of the emperors concerned, in the case of Gordian I and II an important warning has to be made. At least one city Perge on the southern shore of Anatolia - is known to have erected statues for the elder Gordiani on the occasion of a visit of Gordian III Augustus in $\mathrm{AD} 242-243 .{ }^{8}$ We have to accept, therefore, the possibility, that coins were also issued later as commemoratives. In any case, the choice of the portrait and the legends lay with the issuing city itself.

Yet, the question arises whether the emperors did not impose their view on their subjects in the provinces and officially sent forth their personal portraits in hopes of a correct and dignified representation on coins and in statues. Swift has argued that "from the middle of the third century certainly, the custom prevailed of officially sending forth, upon the accession of each new emperor his portraits crowned with laurel to the provincial cities." ${ }^{19}$ Wegner ${ }^{10}$ suggests that most portraits found in the provinces were either Roman export products or copies from official portraits. Also Graindor assumes that

\footnotetext{
${ }^{7}$ On the question whether the emperor surveyed the minting of coins, see Ando 2000, op.cit. (n. 6), 215-228.

${ }^{8}$ This might have been an indication of the hope of the provincials for a new imperial dynasty, a wish also the Roman populace clearly cherished, given its demand to raise Gordian III to power, together with the two senatorial emperors. Apparently few outside the senate were interested in the return to old senatorial values, and most preferred hereditary rule.

${ }^{9}$ E.H. Swift, 'Imagines in Imperial Portraiture', American Journal of Archaeology 27 (1923), 297.

${ }^{10}$ Die Herrscherbildnisse in antoninischer Zeit (Berlin 1939), 11-13.
} 
Egyptian imperial portraits were copied from official models. ${ }^{11}$ Stuart, however, believes that the distribution of the imperial portraits of succeeding dynasties throughout the first and second centuries was not led by official channels. In his view, "only with the anarchy of the third century did political and economic conditions make necessary the use of official imagines in the distribution of imperial portraits." 12

Indeed, from the fourth century on, the literary evidence on this subject is plentiful. But Ando suggests a much earlier date, perhaps from the first decade of the first century $\mathrm{AD}$, for the custom of sending out official portraits at each imperial accession. ${ }^{13}$ If there is a connection between the representation of the emperors of 238 on provincial coinage and the portraits in Rome, we might conclude also for these short reigning rulers that they made conscious efforts to present themselves as legitimate rulers to their subjects.

When the first coins of Maximinus were struck at Rome, he was clearly unknown to the die-cutters, for he had never set foot in the capital. They depicted him as a Severan emperor, a neutral portrait that even if it would not please the emperor, certainly would do no great harm. ${ }^{14}$ In fact, the style of the coins on the whole is quite similar to that of Severan coinage. Towards the end of his reign the emperor's features become very distinct: ${ }^{15}$ he has a prominent nose and chin, a beard, and a rather rough look or as Carson describes the portrait: "the head is very much broader, furrows and lines are emphasised more, and the jaw is positively prognathous". ${ }^{16}$ This can very well be the portrait of a man of about 65 , the age he had probably reached in 238 . ${ }^{17}$ Herodian as well as the Historia Augusta mention that together with the message of his Germanic victories, Maximinus sent pictures of the battles to the capital ${ }^{18}$ If this report is correct, he would have featured prominently in these depictions so that the Roman die-cutters might have had the

\footnotetext{
${ }^{11}$ Bustes et statues portraits d'Egypte romaine (Cairo 1939), 19, $29,34$.

${ }^{12}$ M. Stuart, 'How were Imperial Portraits distributed throughout the Roman Empire?' American Joumal of Archaeology 43 (1939), 617. On coinage, see the contribution to this volume by O.J. Hekster.

${ }^{13}$ Ando 2000, op.cit. (n.6), 229-230.

${ }^{14}$ E.g. RIC IV 2, Maximinus, nr 1, plate 10.1 (Pl. VIII, fig. 1).

${ }^{15}$ E.g RIC IV 2, Maximinus, nr 85, plate 11.2 (Pl. VIII, fig. 2).

${ }^{16}$ R.A.G. Carson, Coins of the Roman Empire in the British Museum. VI. Severus Alexander to Balbinus and Pupienus (London 1962), 95-96.

${ }^{17}$ Zonaras, 12.16.

${ }^{18}$ Herodian, 7.2.8.
} 
opportunity of getting acquainted with the real looks of their emperor, ${ }^{19}$ even though he never came to Rome himself. The most logical explanation for such a drastic change of the image seems indeed to have been an attempt to approach reality. It has also been suggested, though, that the portrait might have been subject to some physiognomic influences. ${ }^{20}$ Whatever the case, it seems safe to conclude that this later depiction of Maximinus Thrax is in fact a real portrait. ${ }^{21}$

According to Herodian, Maximinus was "by his birth and normal behaviour a barbarian. Possessing the bloodthirsty temperament derived from his ancestors and his country, he devoted himself to strengthening his rule by cruel actions. He was afraid that the senate and his subjects would despise him". ${ }^{22}$ Through his coinage, Maximinus may have tried to inspire awe, and to legitimise his power.

Probably in 236, he ordered the deification of his deceased wife, an occasion that was celebrated with an issue of consecration coins. Some of the greatest empresses had preceded Paulina in this honour, and for Maximinus, it was certainly a clear way of asserting his legitimacy. The die-cutters, on the other hand, who had no idea what the woman had looked like, had to resort to a clever device: the concept of family-resemblance could help them out. ${ }^{23}$ They took the prominent nose and chin of the soldier emperor, his deeply sunken eyes and made her face out of these elements. Following portrait busts of other deified empresses, notably the great Livia, they copied the veil, added underneath it a Severan hairstyle with clear hair waves and a bun in the neck, and there she was: the deified Paulina. ${ }^{24}$

The son Maximus was easier to depict. According to the Historia Augusta, he was put through an intensive literary training by his father, who might have consciously attempted to make his son a more acceptable emperor to the Roman public than he himself was. Despite his father's efforts to make him acceptable to the ruling classes, Maximus was reputed to have been

${ }^{19}$ Carson 1962, op.cit. (n.16), 89; M. Alram, Die Münzprägung des Kaisers Maximinus I. Thrax (235/238) (Vienna 1989), 53.

${ }^{20} \mathrm{M}$. Wegner, 'Bildniskunde römischer Herrscher', in ANRW II 12, 2 (1981), 652.

${ }^{21}$ Maximinus' portraits have been used by several scholars to draw up a plan of the various stages of his coinage. See R. Delbrück, Die Münzbildnisse von Maximinus bis Carinus. Das römische Herrscherbild III 2 (Berlin 1940), who distinguished three portrait types: Feldporträt, consulares Porträt and Triumphalporträt, Alram 1989, op.cit. (n.19); M. Alram, 'Zum Aufbau der Münzprägung des Maximinus I. Thrax', Litterae Numismaticae Vindobonensis 4 (1992), 313-322.

${ }^{22}$ Herodian 7.1.1.

${ }^{23}$ Wegner 1981, op.cit. (n.20), 651 .

${ }^{24}$ E.g. RIC IV 2, Paulina, nr 3 (Pl. VIII, fig. 3). 
excessively insolent and prone to scandalous behaviour. Maximinus strove to present his son as an intellectual, beautiful young successor, and so worthy of a predecessor as Severus Alexander. The coin portrait answers this description. Maximus looks like a young Severan prince, with the facial features, although mollified, of Maximinus himself. ${ }^{25}$ The most significant reverse legend to accompany this portrait was PRINCIPI IVVENTVTIS, a title illustrious princes had carried before him. It seems indeed as though, through his family, Maximinus was making efforts to legitimise his rule.

The mint of Alexandria appears to have understood his intentions. In the first years of his reign this mint portrayed his son Maximus as a little boy, no more than a child. ${ }^{26}$ During the third year of rule, a clear change took place. The boy was turned into a young man, very much similar to previous young princes, or Caesares. ${ }^{27}$ This may point to a conscious effort of the emperor to present his son - in the capital as well as in the provinces - as a man who would be worthy of the throne, in the hope of instituting a new dynasty. Unfortunately, the son apparently did not live up to his father's hopes.

It cannot be determined whether Maximinus exercised any influence on the minting of coins in provincial cities. ${ }^{28}$ Most cities seem to have portrayed the emperor as they preferred to see him. Some of the provincial mints tried to create an accurate likeness, with the same prominent nose and prognathous chin as on the official Roman portrait. ${ }^{29}$ Other towns, however, made no such effort, for they adorned the obverse of their coins with a stylised image of what a "soldier-emperor" should look like in their eyes. The results were often not a flattering picture. On all the provincial coins Maximinus is bearded, and has rough features, but more details were of little

\footnotetext{
${ }^{25}$ E.g. RIC IV 2, Maximus, nr 13 (Pl. VIII, fig. 4).

${ }^{26} \mathrm{Pl}$. VIII, fig. 5 .

${ }^{27} \mathrm{Pl}$. VIII, fig. 6.

${ }^{28}$ Cities that struck for Maximinus are plentiful: Acmonea, Adana, Adramyteum, Alexandria Egypt, Alexandria Troas, Amastris, Amisus, Anazarbus, Anchialus, Andeda, Anemurium Apamea, Aphrodisias, Apollonia, Ariassus, Ascalon, Aspendus, Attalea, Augusta, Bithynium, Bosporus, Brouzus, Byzantium, Caesarea-Germanica, Carallia, Cardia, Casae, Celenderis, Cibyra, Cius, Claudioseleucea, Codryla, Coela, Colophon, Colybrassus, Coracesium, Coropissus, Cotiaeum, Cremna, Cretia-Flaviopolis, Cyzicus, Deultum, Dium, Dorylaeum, Elaea, Ephesus, Etenna, Eucarpea, Flaviopolis, Hadrianea, Heraclea, Ilium, Iotape, Isinda, Iuliopolis, Magnesia, Mastaura, Metropolis, Midaeum, Mylasa, Neapolis, Nicaea, Nicomedia, Ninica-Claudiopolis, Nysa, Olbasa, Orthosia, Panemotichus, Parium, Pella, Perga, Pergamum, Philadelphia, Phocaea, Pogla, Pogla, Prostanna, Prusa, Prusias, Prymnessus, Sagalassus, Saitta, Samus, Sardes, Seleucia, Sibidunda, Side, Sinope, Smyrna, Syedra, Synnada, Tarsus, Thessalonice, Thyateira, Tium, Tius, Tomis, Tralles, Tripolis, and probably many more.

${ }^{29}$ E.g. Deultum (Thrace) (Pl. VIII, fig. 7).
} 
interest to the die-cutters, as Maximinus had in most of the cases never visited their city and was unlikely to do so. A suggestive image was therefore more than sufficient. ${ }^{30}$

Coins of Smyrna and of neighbouring Phocaea (using the same obverse die) are the most telling examples of wishful thinking. Maximinus and his son Maximus are shown seated on the curule chairs, as consuls. The emperor, laureate, is holding a globe and a book roll, while his son is shown bareheaded carrying only a scroll. These coins present an image that was earlier used for Septimius Severus accompanied by his two sons. ${ }^{31}$ It is remarkable that these cities chose this iconography with republican roots for a soldier emperor who seems to have paid little or no attention to his civilian duties, not even setting foot in Rome during his entire lifetime.

When the news of the African insurrection reached Rome, the senate acknowledged the Gordiani as imperatores. The Roman mint reacted decisively. ${ }^{32}$ There is no evidence of an emergency coinage struck in North Africa, but within the three weeks of their reign, coins of high quality were struck in Rome. A well designed set of dies with various reverse-types were cut. There are certainly no signs of careless or hurried workmanship. In fact, the coins are of such high quality that many scholars have taken the Roman coins as evidence that the rebellion was a well-prepared conspiracy against Maximinus. Although there are no certain data on the speed with which dies could be cut and coins struck in the ancient world, the speed of the senate's action in 238 certainly raises wider questions on the distribution of imperial portraits. The fact that the last Roman issue of Maximinus seems to have been very small has led to the suggestion that preparations for the revolution were taking place at the Roman mint. This conspiracy theory is, as all conspiracy theories, as interesting as it is unprovable. Our literary sources, reflecting senatorial perspective, had no reason to disclose the senate's participation in such an intrigue. The other sources, such as the numismatic evidence, can in this case be no more than suggestive. In any case, minting coins would have been one of the first acts of a new emperor seeking to assert his power and legitimacy. As a consequence, prompt minting of coins

\footnotetext{
${ }^{30}$ E.g. Eresus (Lesbus) (Pl. VIII, fig. 8).

${ }^{31}$ K. Kraft, Das System der Münzprägung in Kleinasien während der Kaiserzeit (Berlin 1972), 114 and Table 4; D.O.A. Klose, Die Münzprägung von Smyrna in der römischen Kaiserzeit (Berlin 1987), 20 and Table 52.

${ }^{32}$ The following discussion of the Roman coinage of Gordian I and II is based for a large part on RIC IV 2, 158-164; Carson 1962, op.cit. (n. 16), 97-99.
} 
would have been a logical step, whether before or after the official acceptance of the Gordiani.

The Roman mint issued very rare gold aurei of Gordian I as well as denarii and sestertii for both emperors. Fractional denominations have not been found. On the coin portraits father and son resemble each other closely. Whether these are actual portraits is not clear: they may show nothing more than an older and a younger man, taken into account the brevity of their reign and the fact that they were not present in Rome at the time. Furthermore, very few statues have been attributed to the elder Gordians with any degree of certainty. There is no agreement among scholars concerning the emperors' looks. On the other hand, as they were at the time of their accession senior senators, portraits might well have already been prominent in the capital, so that it is quite possible that the coins present accurate portraits. The style and iconography of the coinage are inspired from Severan coins, and so reflect continuity, be it a conscious choice or not.

The reverse types are all quite common and normal. If they were deliberately chosen, they then stressed the endeavour of the new emperors to ground their rule in the tradition of the good emperors of Rome, ruling with respect for the constitution. Besides one titular type of Gordian I (P.M.TR.P.COS.P.P.: stressing his tribunician and consular power) the legends ROMAE AETERNAE and SECVRITAS AETERNA appear, both of which occur on coins of Severus Alexander. Coins of Gordian II stress the emperors' concern for the well being of Rome and hope of victory by such legends as PROVIDENTIA AVGG, VICTORIA AVGG and VIRTVS AVGG. The aes coinage carries similar images and legends except for a type exclusive to Gordian I that reads VIRT. EXERCIT. S.C. Since the new rulers lacked support of the army, choosing this legend seems either an act of hubris or a desperate hope to sway the army's loyalty. Since Maximinus was murdered by his own soldiers, the type ironically foreshadowed what happened a few months later. On the other hand, coin types might have been chosen as a matter of administrative routine with little conscious plan - a possibility that seems less plausible to me.

As for the provinces, Herodian reports that "the senate... did their best to rouse (them). Delegations of special senatorial representatives and well-known members of the equestrian order were sent in all directions to visit all provincial governors. Letters also went out to explain the position of the Romans and the senate, and to urge governors to join sides with those 
who were planning for their common state and its senate; the provincial population was told to remain loyal to the Romans". ${ }^{33}$

Herodian also tells us that in Africa "all the honorary dedications to Maximinus were torn down, and in their place the cities were adorned with portraits and statues of Gordian (I)"34 and that "all the statues, pictures and honorific dedications of Maximinus were torn down". ${ }^{35}$ It can be deduced from the literary sources that Maximinus desperately tried to reassert himself. His loyal legate of Numidia, Capellianus, attacked and punished the cities that had accepted the Gordiani as soon as the two African emperors were dead. ${ }^{36}$ In at least three cities of Asia Minor the coins of Maximinus suffered damnatio memoriae. ${ }^{37}$ Several examples of damnatio memoriae are known from Pergamon, although at least one coin survives where the erasion was not executed ${ }^{38}$ Smyrna, after first depicting the emperor as consul, erased his image from coins as well. On one of them a primitively drawn star is carved, as if to emphasise the damnatio memoriae. ${ }^{39}$ Also from Elaea, the port of Pergamum, a single specimen is known of an erased coin of the Thracian emperor. ${ }^{40}$ The erasures were to all probability not carried into effect while Maximinus was still alive. Many of portraits were probably chiselled off as soon as the citizens heard of Maximinus' death.

The same point holds true for cities coining for the two Gordiani. After eliminating all known forged coins of the African emperors, ${ }^{41}$ the remaining coins are few. Besides Alexandria in Egypt, coins survive from only two other cities: Prymnessus in Phrygia, and Aegeae in Cilicia. In the

\footnotetext{
${ }^{33}$ Herodian 7.7.4-5.

${ }^{34}$ Herodian 7.5.8.

${ }^{35}$ Herodian 7.7.2.

${ }^{36}$ Herodian 7.9.11; Historia Augusta, Vita Max. 19.4; Gord. 9.3; on one inscription (CIL 8.757 and 10047) the name of Maximinus was re-inscribed after having been erased; C.R. Whittaker, Herodian. Books V-VIII (Cambridge MA/ London 1999 [= 1970] ), 188 n. 2.

${ }^{37} \mathrm{R}$. Mowat, 'Martelage et abrasion des monnaies sous l'empire romain', Revue Numismatique 4, 5 (1901), 443-471; 4, 6 (1902), 286-290, 464-467; K. Regling, 'Zur griechischen Münzkunde III. Erasionen', Zeitschrift für Numismatik 24 (1904), 134-144; R. Münsterberg, 'Damnatio Memoriae', Monatsblatt der numismatischen Gesellschaft in Wien 11 (1918), 32-37; P. Berghaus, 'Erasionen auf Münzen aus Pergamon in der Sammlung Th. Bieder der Westfalischen Wilhelms Universität', Studien zur Religion und Kultur Kleinasiens, ed. S. Sahin (Leiden 1978), 158-162; K. Harl, Civic Coins and Civic Politics in the Roman East, AD 180-275 (Berkeley 1987), 34-35, 150-151 n. 36.

${ }^{38} \mathrm{H}$. Dressel, 'Erwerbungen des Königlichen Münzcabinets in den Jahren 1898-1900', Zeitschrift für Numismatik 24 (1904), 17-104.

${ }^{39}$ Klose 1987, op.cit. (n. 31), 119 and Table 52.

${ }^{40} \mathrm{Pl}$. VIII, fig. 9.

${ }^{41}$ Antiocheia, Byzantium, Heraclea Pontica, Caesarea Germanica, Corcyra, Maeonia, Miletus, Myra, Samus and Smyrna; H. Von Aulock, Münzen und Städte Phrygiens 2 (Tübingen 1987), 44-46.
} 
case of Alexandria, most likely the coins were struck before the news of the emperors' death reached the city. ${ }^{42}$ The portraits on the Alexandrine coins are stylised but so were those of other emperors at this mint, so personalised features can seldom be detected

The coins of the other two cities have given rise to debate. Bosch believed that the Gordiani were never acknowledged in Asia Minor, as these provinces remained under the domination of Maximinus. Therefore, no coins could have been struck during the lifetimes of the Gordiani so that their coins that cannot be dismissed as forgeries had to be struck under Gordian III as commemoratives. These coins were thus analogous to the statues at Perge. The coin of Prymnessus would have been an example of this. ${ }^{43}$ But von Aulock has argued, on the basis of milestones found in Galatia, that the Gordians were accepted in some areas in Asia Minor. Based on the imperial, he reasons that the coins were struck during their lifetimes. ${ }^{44}$ Prymnessus is an odd place to strike coins, especially for such short-reigning emperors. Even though von Aulock believes the city was a commercial centre, it was located far inland, so that it would have taken time for the news to arrive. Since no ancient sources save for Ptolemaeus ${ }^{45}$ and some Christian texts mention the town, Prymnessus was hardly an important city. It is an enigma as to why such a small town minted coins for the Gordiani, and then a few months later for Pupienus and Balbinus. ${ }^{46}$ The most plausible solution is that some prominent inhabitants of the city who had visited Rome returned with the news, faster than it could be announced through the official channels. On their report, the town, for reasons unknown to us, decided to strike the coins. It could have been sudden need for money in tandem with civic pride and hopes of imperial favour.

Aegeae, on the other hand, was home to a major sanctuary of Asclepius and a strategic port on the route between Syria and Cilicia Pedias. This city asserted its virtues whenever possible, as did its rivals Anazarbus and Tarsus. ${ }^{47}$ In my opinion, Bloesch correctly points out that there is no

\footnotetext{
${ }^{42} \mathrm{H}$. Bloesch, Erinnerungen an Aigeai (Winterthur 1989), 16 suggests that it took the news 20 days to reach Alexandria from Rome.

${ }^{43}$ C.E. Bosch, 'Münzen Gordians I aus Kleinasien', Anadolu Arasztirmalari 1 (1955-1959), 203-205.

${ }^{44}$ Von Aulock 1987, op.cit. (n. 41), 50; the linear form of sigma and epsilon on portrait coins seems to be the trademark of one die-cutter, working in the year 238 .

${ }^{45}$ Ptolemaeus 5.2.24.

${ }^{46}$ Von Aulock 1987, op.cit. (n. 41), 51.

${ }^{47}$ P. Weiss, 'Ein Altar für Gordian III, die älteren Gordiane und die Severer aus Aigeai (Kilikien)', Chiron 12 (1982), 190-205.
} 
reason to be surprised ${ }^{48}$ about the fact that a coin of the Gordians from this city is known. ${ }^{49} \mathrm{He}$ argues that, along with the dispatches of messengers to the provinces, the senate also sent official portraits. This fact can also be deduced from Herodian's statement. ${ }^{50}$ Moreover, Cilician cities seem to have been especially assiduous in minting coins in the first half of the third century. Eighteen cities coined for Maximinus and at least seventeen for Gordian III. ${ }^{51}$

At Aegeae an altar has been found, with two dedications to Gordian III, the theoi Gordianoi I and II, and a third inscription honouring the theoi sebastoi Severus Alexander, Septimius Severus, Caracalla and Iulia Domna. All three inscriptions are from different hands, and they might have been cut in the year 238. What is significant is the city's linking of Gordian III to the Severan dynasty. This action by the Cilician city probably reflected official ideology, best seen on the style and iconography of the coins struck at Rome. Aegeae did not mint coins under Maximinus, but the absence of coinage in itself does not indicate hostility or rejection of the soldier. ${ }^{52}$ Far more likely, the city had struck an abundance of coins under previous emperors so that it saw no particular need to coin under Maximinus. ${ }^{53}$ In any case, the city immediately presented itself as loyal to the teams of senatorial emperors, first the Gordiani and then Balbinus and Pupienus.

When the news of the death of the Gordiani reached the capital, the Roman mint immediately started issuing for the new senatorial emperors, Balbinus and Pupienus. ${ }^{54}$ Their coins struck at Rome are more diversified than those of Gordian I and II are, but these too were not abundant. A handful of aurei were struck for both emperors, as were also some silver denarii. Most of the silver coins are antoniniani, the double denarii that they reintroduced to remedy their shortage of money. The aes coinage consists of mostly sestertii, along with some dupondii and a few asses.

Some significant reverse types reflect aspects of their political program. Besides a titular type for both emperors, six other reverse types can be found on the denarii, three for each emperor. LIBERALITAS obviously

\footnotetext{
${ }^{48}$ Bloesch 1989, op.cit. (n. 42), 23.

${ }^{49}$ A. von Sallet, 'Die Namen der beiden ersten Gordiane', Zeitschrift für Numismatik 7 (1880), 140; D. Nony, 'Une monnaie de Balbin à Aegeae de Cilicie (238 ap. J.C.)', Bulletin de la Société Française de Numismatique 27, 7 (1972), 244.

${ }^{50}$ Bloesch 1989, op.cit. (n. 42), $15-18$ counts 25 days at the speed of $137 \mathrm{~km} / \mathrm{d}$ to reach Aegeae from Rome.

${ }^{51}$ Nony 1972, op.cit. (n. 49), 244.

${ }^{52}$ Weiss 1982 , op.cit. (n. 47), 197.

${ }^{53}$ Nony 1972, op.cit. (n. 49), 244.

${ }^{54}$ Much of the following discussion found its origin in RIC IV 2, 165-176; Carson 1962, op.cit. (n. 16), 99-104.
} 
refers to the donative, given out at the time of the coronation. ${ }^{55}$ The appeals to IOVI CONSERVATORI and PROVIDENTIA DEORVM not only called for the protection of the gods, but also for divine sanctioning of the new rule. Types associated with the legends PAX PVBLICA, CONCORDIA AVGG and VICTORIA AVGG expressed either hopes of a quick victory or became in effect a triumphal coinage upon the death of Maximinus. The antoniniani all feature on the reverse clasped hands with the legends CONCORDIA AVGG, FIDES MVTVA AVGG, PIETAS MVTVA AVGG (for Balbinus) and AMOR MVTVVS AVGG, CARITAS MVTVA AVGG, PATRES SENATVS (for Pupienus). This array of types emphasised the ideal of the senatorial tradition and respect for the laws, but foremost the ideal of the double dominion, reminiscent of the old times of the republic. ${ }^{56}$ The reality was different, with both emperors suspicious and full of envy for each other, an attitude that would speed up their downfall.

The portraits on the obverses of the coins have every appearance of being realistic. Since Balbinus and Pupienus were in Rome at the time of their election to the principate, they enjoyed a great advantage: they were known to their subjects. The most eye-catching feature of Pupienus' image is his long, full beard. ${ }^{57}$ According to Bastien ${ }^{58}$ this type of beard, also worn by Pertinax ${ }^{59}$, Didius Julianus and Macrinus, was the last manifestation of a long gone fashion. Based on sculpture portraits, Kleiner makes the telling observation that, "By having himself depicted with an Antonine beard, he emphasised his senatorial side and his descent from such good emperors of the past as Marcus Aurelius." ${ }^{160}$ Balbinus can be recognised from his heavy jaw and fleshy features. ${ }^{61}$

As previously argued, we can be reasonably sure that the portraits on the obverse of their Roman coinage are accurate. If so, the question is raised as to whether the new government cared at all to send along with the message of their accession accurate portraits also to the provinces, to give faces to the new people in power. Herodian mentions the presence of pictures

\footnotetext{
${ }^{55}$ The Chronographer of the year 354 and Herodian 8.7 .7 both mention a generous distribution of money.

${ }^{56}$ Whittaker 1970, op.cit. (n. 36), 299 n'. 2; 303 n. 3.

${ }^{57}$ E.g. RIC IV 2, Pupienus, nr 22a (Pl. VIII, fig. 10).

${ }^{58} \mathrm{P}$. Bastien, Le buste monétaire des empereurs romains (Wetteren 1992-1994), 28.

${ }^{59}$ Delbrück 1940, op.cit. (n. 21), 69.

${ }^{60}$ D.E.E. Kleiner, Roman Sculpture (New Haven/London 1992), 365.

${ }^{61}$ E.g. RIC IV 2, Balbinus, nr 16 (Pl. VIII, fig. 11).
} 
of Pupienus, Balbinus and Gordian III in the beleaguered Aquileia when Maximinus was killed. ${ }^{62}$

The surviving statues of both emperors depict them after the fashion of their coin portraits. ${ }^{63}$ Most significant is the pair of statues of Balbinus and Pupienus, each of whom is cast as Jupiter, ${ }^{64}$ that were salvaged from a shipwreck off the Piraeus. Although the statues are not of a high artistic quality, they demonstrate that there was an immediate market for images of these emperors. Given their find spot, these statues were either made in Athens to be exported to a shrine or a public space or they were being imported into Athens when the ship went down. ${ }^{65}$ It is not clear when the statues were created either. Although they might have been ordered during the lifetime of the senatorial emperors, they could also have been made under the rule of Gordian III. ${ }^{66}$ The iconography of a statue of Balbinus on his sarcophagus is most instructive, for he is presented both as a togate senator, reclining on the top of the lid, and as an army commander on the side of the coffin. Therefore, he is represented both performing his civil and his military duties, although his function as a civil magistrate has received preference over his task as a general.

Most specimens of provincial coins exhibit fairly accurate portraits of the emperors. ${ }^{67}$ In contrast to Maximinus, images of Balbinus and Pupienus were apparently known in the provinces because either these emperors were quick to send pictures or were already known at their accession due to their connections with local elites or contacts acquired while discharging their senatorial duties in the provinces. Among the cities to mint coins were Prymnessus and Aegeae, the two cities that had coined for the Gordiani. Among others was the major mint of Tarsus, the first city of Cilicia and favoured by Severan rulers. ${ }^{68}$ Balbinus and Pupienus must have appreciated the importance of being accepted by the cities of the East.

\footnotetext{
${ }^{62}$ Herodian 8.6.2: "Aquileian commanders ... brought out pictures of Maximus, Balbinus and Gordian Caesar wreathed in crowns of laurel, which they cheered."

${ }^{63}$ The coin images are so much like the statue portraits that they helped to identify a sculpture head of Balbinus. See H. Jucker, 'A Portrait Head of the Emperor Balbinus', The Bulletin of the Cleveland Museum of Art (1967), 11-16.

${ }^{64}$ Based on the example of statues of Claudius as Jupiter: Kleiner 1992, op.cit. (n. 60), 366.

${ }^{65}$ C.C. Vermeule, Roman Imperial Art in Greece and Asia Minor (Cambridge MA 1968), 314.

${ }^{66}$ Vermeule 1968, op.cit. (n. 65), 310.

${ }^{67}$ Pupienus: Miletus, Prymnessus, Heraclea, Nicomedia, Prusa, Tarsus, Pupienus-countermark on a coin of Erythrae, Hadrianopolis; Balbinus: Aegeae, Amisus, Heraclea, Milete, Tarsus, Thessalonica and Hadrianopolis.

${ }^{68} \mathrm{Pl}$. VIII, figg. 12 and 13.
} 
In addition, many Asian cities might have coined in anticipation of a campaign by Pupienus against the Sassanids. ${ }^{69}$ The Historia Augusta is the only literary source that mentions this expedition and has not yet been confirmed by any other source, but the striking of civic bronze suggests preliminary mobilisation in the eastern army was under way in 238 . The reverse of a Nicomedian coin of Gordian III Caesar shows the emperor in a military cloak, being crowned by Nike and sacrificing to the gods. Another reverse depicts an equestrian emperor, either Pupienus or Gordian III Caesar, with his lance positioned for attack. ${ }^{70}$ The coins of Tarsus also support this hypothesis. Military types were found on the reverses of Pupienus' coins (notably the emperor with a trophy, the goddess Nike and the emperor spearing a lion). Moreover, the large volume of coins struck by Tarsus for both emperors suggests that the city was providing fractional bronze currency in anticipation of the aurei and denarii that would be spent in local markets by soldiers on campaign. ${ }^{71}$ Tarsians almost certainly were expecting an offensive by these emperors against the Sassanids. ${ }^{72}$

In the city of Rome the emperors used their coins to present themselves as legitimate rulers and to promote their program to urban plebeians, Senate, and Praetorian Guard. The style and iconography of the coinage of Maximinus, as well as that of the senatorial emperors, was Severan in inspiration and presented a continuation of appeals of the Severan dynasty. Reverse types of the coins seem to have been deliberately chosen. The legends on the coinage of Balbinus and Pupienus, for example, harkened back to a restoration of a traditional order replete with Republican ideals. In the provinces attention was paid to the choice of reverse types. The military types on the coins of Tarsus indicate expectation of an expedition of Pupienus to the East.

In their official portraiture, Roman emperors made every effort to legitimise their reign and present themselves to their subjects as acceptable rulers. Maximinus, for one, might have tried to overcome the suspicion the senate nursed against him by portraying his family as an impeccably imperial

\footnotetext{
${ }^{69}$ SHA, Max. et Balb.13.5.

${ }^{70}$ C.E. Bosch, Die kleinasiatischen Münzen der römischen Kaiserzeit 2.1.1: Bithynien (Stuttgart 1935), 293-294; R. Ziegler, Städtisches Prestige und Kaiserliche Politik. Studien zum Festwesen in Ostkilikien im 2. und 3. Jhr. n.Chr. (Düsseldorf 1985), 139.

${ }^{71} \mathrm{~K}$. Harl, Political Attitudes of Rome's Eastern Provinces in the Third Century A.D. (Ph.D. Yale 1978), 28, 142 n. 42, 428; Ziegler 1985, op.cit. (n. 70), 139-140.

${ }^{72}$ SHA, Max. et Balb. 13.5; Zonaras 12.18 for a possible Persian threat and the fall of Nisibis and Carrhae, but the last is contradicted by Herodian 7.8.4.
} 
family, with a young successor and a deified empress. If the literary sources are to be trusted, unfortunately his son Maximus refused to play the role and so earned himself a bad reputation. The Gordiani reigned for too short a period to make effective any of the promises presented on coins.

Balbinus and Pupienus undoubtedly linked themselves to Severan, Antonine, and even Republican traditions. In the East, the numbers of their coins and statues are surprisingly high, given the brevity of their reign. What is even more impressive is the accuracy of the imperial portraits. This precision, along with the speedy appearance of the likenesses, indicates that, at least for the larger cities, there was an official means for sending out imperial portraits. In the case of smaller provincial towns circumstance and lines of patronage probably dictated early distribution of imperial portraits.

In my opinion, the coins indicate that the emperors of 238 sought to make themselves known in the provinces. Roman emperors depended on the goodwill of the provincial cities. They were customarily presented the way a provincial city wished to see them, even if such depictions did not coincide with the reality as in the case of Maximinus' coins. In the case of Balbinus and Pupienus, there seem to have been conscious efforts by the emperors to be portrayed correctly and by the cities to disseminate quickly this accurate image. It is most reasonable to surmise, although it cannot be proved conclusively, that these attempts resulted from senatorial sympathies among the local elites. As for Gordian I and II, their reigns were too short, and their portraits too few to draw many conclusions. Even so, we cannot help but be amazed as to how quickly some provincial towns accepted these two rulers. This very speed hints at efforts to promote these rulers as well. Facing Maximinus at the head of the daunting frontier legions, the African emperors had every reason to canvass for supporters across the empire.

Leuven, September 2002 